\title{
Perspectives of EMPloyee Training AND DeVElopMENT: METHODS AND APPROACHES
}

\author{
Kateřina Maršíková ${ }^{1}$; Eva Šlaichová ${ }^{2}$ \\ Technical University of Liberec, Faculty of Economics, \\ Department of Business Administration, \\ Studentská 1402/2, 46117 Liberec 1, Czech Republic \\ e-mail: ${ }^{1}$ katerina.marsikova@tul.cz; ${ }^{2}$ eva.slaichova@tul.cz
}

\begin{abstract}
The aim of this paper is to give a topical overview of the trends, methods and approaches in respect to employee training in companies by presenting primary and secondary data received from surveys. Based on the findings of scientists and HR specialists, employee training is an important form of company investment that generates additional value and increases a firm's productivity. At the same time, it has an impact on human capital. When training employees, companies can have different motives and use different methods that are described in the first part of this paper. The second part of the paper compares the position of training in European companies and those in the U.S. The last part introduces the methods and reasons for training based on a sample of Czech respondents. The results show that in some Czech companies, the training scheme is not systematic or does not exist at all. In addition, secondary data from the surveys point out that there is a significant number of companies that do not provide any training at all.
\end{abstract}

\section{Introduction}

Employee training is currently one of the core HR activities. Having well-trained employees with sufficient knowledge and skills gives companies an important competitive advantage as well as higher value of their intellectual capital. From the employee point of view, the opportunity to receive additional training leads to both greater motivation and loyalty within their firm. Training is also presented as one of the most common employee benefits (see i.e. surveys [11]) and at the same time it is an important factor that affects a company's productivity and success (as confirmed by several studies [2]; [3]; [4]; [13]; [15]).

As Becker points out, training is one of the most important investments in human capital and leads to an increase in employee human capital. Human capital is one of the key parts of a company's intellectual capital that is included in its intangible assets [6]. Developing intellectual capital is related to the need for companies to develop their employees' knowledge and skills. Employee training is a form of education that differs from formal education and is directly related to the given work tasks and needs. Therefore, it brings revenues to both individuals and directly to the company. One benefit of training is primarily economic, both for a company and an individual. It is possible to use different methods of training to deepen abilities and competencies. An example is training at the workplace (onthe-job training), i.e. training managers or colleagues at work through observation. If we look at education from the perspective of the human capital model, individuals maximize their lifetime wealth through investments in education. For the company, the demand for staff training is a function of training costs and the rate of technological progress [14]. 
The aim of this paper is to provide an actual view of the trends, methods and approaches taken with regard employee training in firms by presenting both primary and secondary data received from surveys. Many studies have shown that investing in employee training and development has more substantial business effects than investing in equipment and other material resources. Nevertheless, just like any other investment, investing in training is connected with risk, especially in losing trained workers who, when they leave a company, take their skills and knowledge with them.

The knowledge gained from formal education can be used in any enterprise. However, specific training is more advantageous for companies. Its financing may be provided either by the company or by the employee. Companies are reluctant to invest in general training, because this knowledge can be used by the employees in any company and the return on investment for the company is therefore very uncertain.

Training in companies belongs to the process of continuing vocational training as a long term process of developing of abilities and competencies. On-the-job and of-the-job training is supported by personal and working experience and aims to optimise the development of their potential and structure of their competencies [18].

Although there is general agreement about the importance of training as a tool to help companies in developing sustainable competitive advantages based on their human resources, this investment is still relatively low compared to other forms of investment in firms. Therefore, this situation is also supported and confirmed by the data presented in the empirical part of this paper, which were data received from surveys regarding companies' experience with training part-time students. Among other reasons, this is due to the fact that companies do not evaluate the effects of training on performance and therefore they do not know its economic impact on the company [4].

For the first part of the paper, theoretical background of training in companies and methods of employee training were introduced. The second part follows the theoretical background in a practical application on data from secondary and primary surveys to highlight a situation in employee training. The primary data introduced in the last part were obtained in the survey run at the Faculty of Economics, Technical University of Liberec in 2013 and 2014 that were given to part time students of this faculty.

The current situation with regard to company training is presented using both international and Czech data in the second and third parts of the paper. This data were collected through responses received to a questionnaire survey that was distributed to part-time students focused on company training. Despite the fact, that this survey has limitations generalizing its results, it brings topical information about an application and using of training methods.

\section{Defining Training and Development}

Training can be understood as a synonym for instruction. Training includes the set of tools, methods and content which, when combined, create a purposeful approach to instruction. Training refers to a planned effort by a company to facilitate their employees' learning of jobrelated competencies. These competencies include knowledge, skills and behaviours that are critical for successful job performance in the immediate term or near future. By contrast, development is a training that provides employees with competencies for anticipated future jobs and roles. For a maximal efficiency for companies as well as individuals it is important to have it in a systematically framework [17, 19]. 
Training and development are built into the organizational context and the environment. They are derived from this context and they are further subjected to the influence of other processes related to human resources, such as e.g. evaluating safety and working efficiency. Training itself is a process; it is a series of individual steps that lead to improved performance and should be interconnected with employee evaluation.

\subsection{Methods of Employee Training}

Vocational education and employee training is a systematic adaptation of learning that occurs as a result of education and the acquisition and development experience. It is provided within employee daily duties or separately. Table 1 introduces commonly used methods of vocational education and training.

Tab. 1: Methods of vocational education and employee training

\begin{tabular}{|l|l|l|}
\hline Method & Characteristics & Used forms of training \\
\hline $\begin{array}{l}\text { on-the-job } \\
\text { training }\end{array}$ & $\begin{array}{l}\text { used in everyday } \\
\text { practice as a part of a } \\
\text { training program } \\
\text { (tailor-made) }\end{array}$ & $\begin{array}{l}\text { demonstration, coaching, job rotation, mentoring, } \\
\text { counselling, workshops, assisting }\end{array}$ \\
\hline $\begin{array}{l}\text { off-the-job } \\
\text { training }\end{array}$ & $\begin{array}{l}\text { used in training } \\
\text { courses held in } \\
\text { traditional educational } \\
\text { institutions }\end{array}$ & $\begin{array}{l}\text { lectures, discussions, method of discovery, } \\
\text { workshops, simulations, assessment centres, } \\
\text { role playing, case studies, brainstorming, } \\
\text { team building, learning within games, seminars }\end{array}$ \\
\hline $\begin{array}{l}\text { on-the-job and } \\
\text { off-the-job } \\
\text { training }\end{array}$ & $\begin{array}{l}\text { to be proceeded by the } \\
\text { above-mentioned ways }\end{array}$ & $\begin{array}{l}\text { briefings, questions and answers, learning events, } \\
\text { task delegation, study recommended literature, } \\
\text { e-learning, interactive videos, } \\
\text { multimedia education }\end{array}$ \\
\hline
\end{tabular}

Source: [5], [12], author's own adaptation

In the context of training, it is possible to use a wide variety of methods that can be divided according to where these educational activities take place. Some methods blend together or follow one another. The choice of method depends on the specific needs and objectives of the training program. In general, we can say that in the case of blue-collar professions, procedures for training at the workplace are primarily applied, whereas for managerial positions, methods for training outside the workplace are increasingly used. In some companies, on-the-job training constitutes $85 \%$ of all educational activities [5].

Since training methods have started to be used in companies, trainers, teachers and professors have developed a number of techniques used in business education. Although there is now a general shift from passive to active learning methods, it remains useful as many of the old ways of teaching. In addition, there is a tendency to combine these teaching methods (see Tab. 1).

A practical use of the methods listed above illustrates data from surveys presented below. Choosing a particular method of training depends on different aspects. Typically, on-the-job training methods are used for practical application mainly for manual-workers, however they are currently also being used for administrative staff as well as managers. The results of data from Saks indicate the transfer of training is positively related to firm performance and mediates the relationship between training methods and firm performance. Their results also suggest that among the three training methods mentioned above, on-the-job training was the most strongly related to the transfer of training and firm performance [15]. 
On-the-job training is provided in two forms:

- General training at the workplace - this is an investment in human capital that is effective in increasing the productivity of both individuals in a company that provides this education, as well as for other companies. It is useful in many firms besides those providing it. In other words, "perfectly general" training would be equally useful in many firms and marginal products would rise by the same extent in all of them [6].

- Specific training at the workplace - this form of training increases productivity only in the company that provides this education, but has either no or only a limited effect on productivity elsewhere.

The effect of investment in employee productivity elsewhere depends on market conditions and on the nature of the investment. If all training were completely specific, the wage that an employee could get elsewhere would be independent of the amount of training he/she had received.

From the HR management point of view, on-the-job training is the most important form of human capital development. It's not just because the training is given by the company itself, but mainly because the method and timing must be aligned with the business needs [7]. Becker emphasises that many workers increase their productivity by learning new skills and perfecting old ones while on-the-job. Future productivity can be improved only at a cost, for otherwise there would be an unlimited demand for training [6].

In last few years, companies have moved from traditional methods to those that are more interactive and easy to reach. Firms talk about e-learning, blended learning, gamification and shadowing as those that are becoming more and more popular. This confirms data from surveys taken on employee training worldwide in the chapter 3.

\section{$3 \quad$ Company Training Worldwide}

Many surveys searching for information about employee training, methods used for training, popular trained topics as well as effects on company competitiveness and business results both in Europe and worldwide have been conducted. Several studies have emphasised that training can have a positive effect on company performance by raising labour productivity, improving the organisational culture and encouraging innovation [8]. For example, Cedefop reported that Austrian companies that doubled their investment in training increased their productivity by $4 \%$ and pay higher wages [9].

Despite the critical role of continued investment in vocational-oriented learning, many EU firms do not provide training to their employees. Data from the CVTS3 reveal that a sizeable $40 \%$ of private firms did not provide any type of continuing training in 2005 (though this figure varies depending on whether firms are permanent or incidental non-trainers). Using a different methodology, the 2009 European company survey (ECS), which surveys a smaller sample of European companies, also indicates that $38 \%$ of firms provide no training [10]. According to CVTS4 in $201056 \%$ of EU companies provided at least CVT courses and $53 \%$ of companies at least the other forms of job-based training [19]. In other words more than $40 \%$ of companies declared that they did not provide any training for employees.

One of other surveys dealing with training in companies was conducted by Accenture and surveyed 400 executives at large US companies. Data from the US show a positive sign; 51 percent of questioned companies expected to increase their investment in training over the next two years. Data from the Accenture 2013 survey also showed nearly three-quarters $(72 \%)$ of executives identified training as one of the top ways for employees to develop new 
skills, while only 52 percent of the workers employed by the companies surveyed currently receive company-provided, formal training [1].

The most popular topics currently trained in US companies include problem solving (78 \%), leadership (75\%) and communication skills (73\%). Specific knowledge such as industry specialisation, analytical skills and functional knowledge were also popular areas in the questioned companies (between $60-70 \%$ confirmed them) [1].

As was mentioned above, there are different methods used to provide employee training. Respondents from the survey conducted by Accenture in 2013 indicated on-the-job training and experience as the most common way to train their employees (see Figure 1) [1]. Surprisingly the second most often used method for training is still formal training (traditional methods) provided by a company.

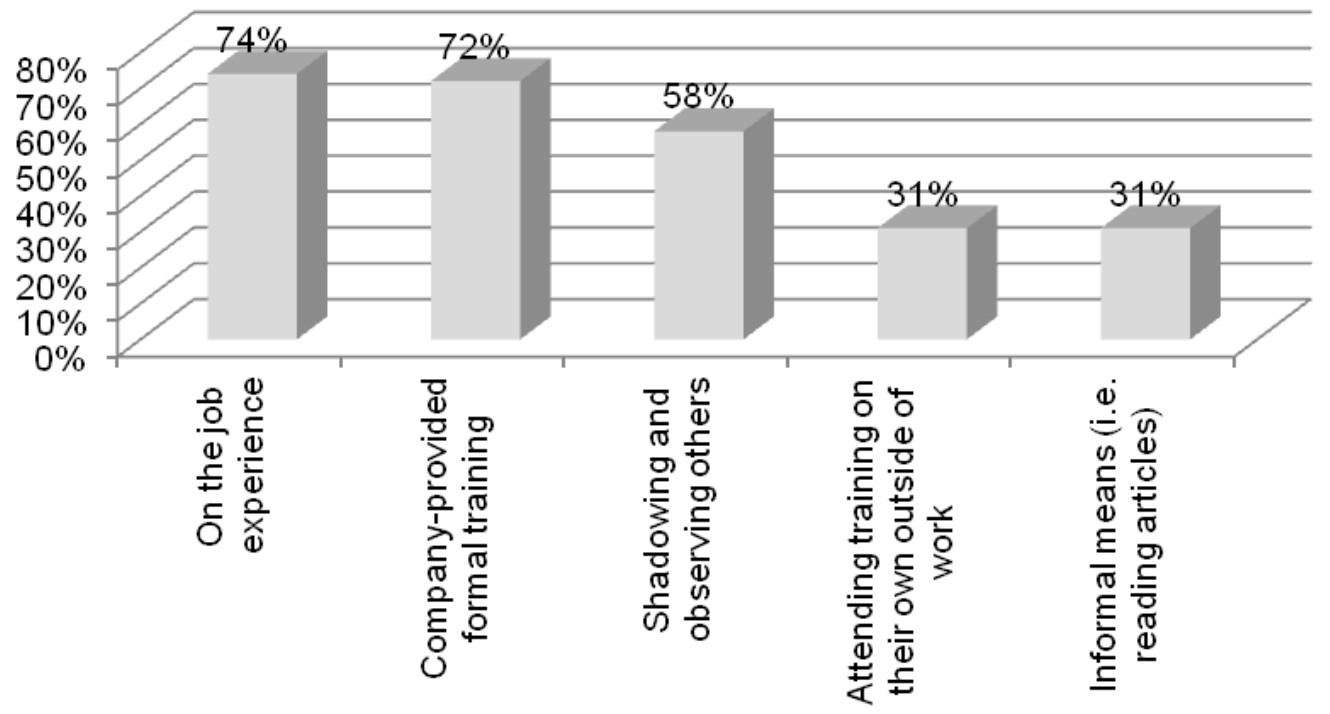

Answers in \%

Source: [1], author's own adaptation

Fig. 1: Popular ways of training in the US in 2013

Respondents were free to describe the approaches employed by their company. In terms of the different methods of competence development, companies primarily take a blended approach towards competence development utilising both internal and external formal training alongside e-learning, coaching, job shadowing and mentoring depending on the needs of the company. Companies often endeavour to find a balance between formal learning, informal learning and implementation of this learning in the daily jobs of their employees.

In European enterprises, it should be highlighted that formal training quite often forms the smallest part of the competence development approach. Formal learning that is used to develop competences is predominantly combined with informal learning to develop the competences of employees. Furthermore, preference is often given to more informal methods of competence development and therefore formal training constitutes the smallest percentage of efforts to improve competences. Many companies mention that they take the 70-20-10 approach, whereby only $10 \%$ of competence development is conducted through formal training. 
The situation in company training in the Czech Republic was mapped through primary data surveys conducted in 2013, 2014 by authors as well as by data presented by e.g. ING [11]. The aim of this chapter is to support updated information base about training and increasing of qualification in companies, methods used for training as well as its importance employees. The authors selected respondents among part-time students of the Faculty of Economics, Technical University of Liberec (EF TUL) and compared data both over two years and with international results. The respondents were selected because they were active in the labour market and thus as employees experience company training. At the same time, they were in the position of investing in their own human capital through increasing their qualifications at university. The questionnaire survey was conducted at the end of 2013 and 2014. Part-time students from all grades at the Faculty of Economics TUL who attended the lectures were personally contacted. In total, there were 161 respondents in 2013 and 70 in 2014 (only first year students were questioned because other students participated in the survey in 2013). More than $62 \%$ of respondents were people younger than 30 years, only $9 \%$ belonged to the age cohort $40-49$ years. There was nobody older than 50 years.

Tab. 2: The number of respondents according to gender

\begin{tabular}{|l|l|l|l|}
\hline Gender & $\mathbf{2 0 1 3}$ & $\mathbf{2 0 1 4}$ \\
\hline Men & 52 & 23 \\
\hline Women & 109 & 47 \\
\hline Total & $\mathbf{1 6 1}$ & $\mathbf{7 0}$ \\
\hline
\end{tabular}

Source: Questionnaire Survey - author's own adaptation, [17]

The structure of the respondents is presented in Tables 2 and 3. The type, form an amount of investment in employee training depends also on a company size. In general, larger companies usually have more resources to invest in employee development. The structure of the respondents according to the size of the company is shown in Table 3 . Nearly $50 \%$ of the companies in which the respondents worked were large companies that most likely care more about training their employees.

Tab. 3: Segmentation of respondents according to the company size

\begin{tabular}{|l|l|l|}
\hline Size of the company & $\mathbf{2 0 1 3}$ & $\mathbf{2 0 1 4}$ \\
\hline Small (less than 50 employees) & 47 & 18 \\
\hline Medium-sized (between 50 - 250 employees) & 33 & 12 \\
\hline Large (more than 250 employees) & $71^{*}$ & 28 \\
\hline
\end{tabular}

* 10 respondents in 2013 did not answer.

Source: Questionnaire Survey - author's own adaptation, [17]

One of the survey focuses was to find out specialisation of training in companies. From the results in Figure 2 can be seen that respondents confirmed the importance of investing into soft skills and language courses. The increase in the area of training can be seen in the field of communication and presentation.

Different aspects play role in specialization of training. It definitely depends on the specialism of employees. These results are not presented because of the limited scope of this paper. However there is a presumption to work on it in the future research of the authors. 


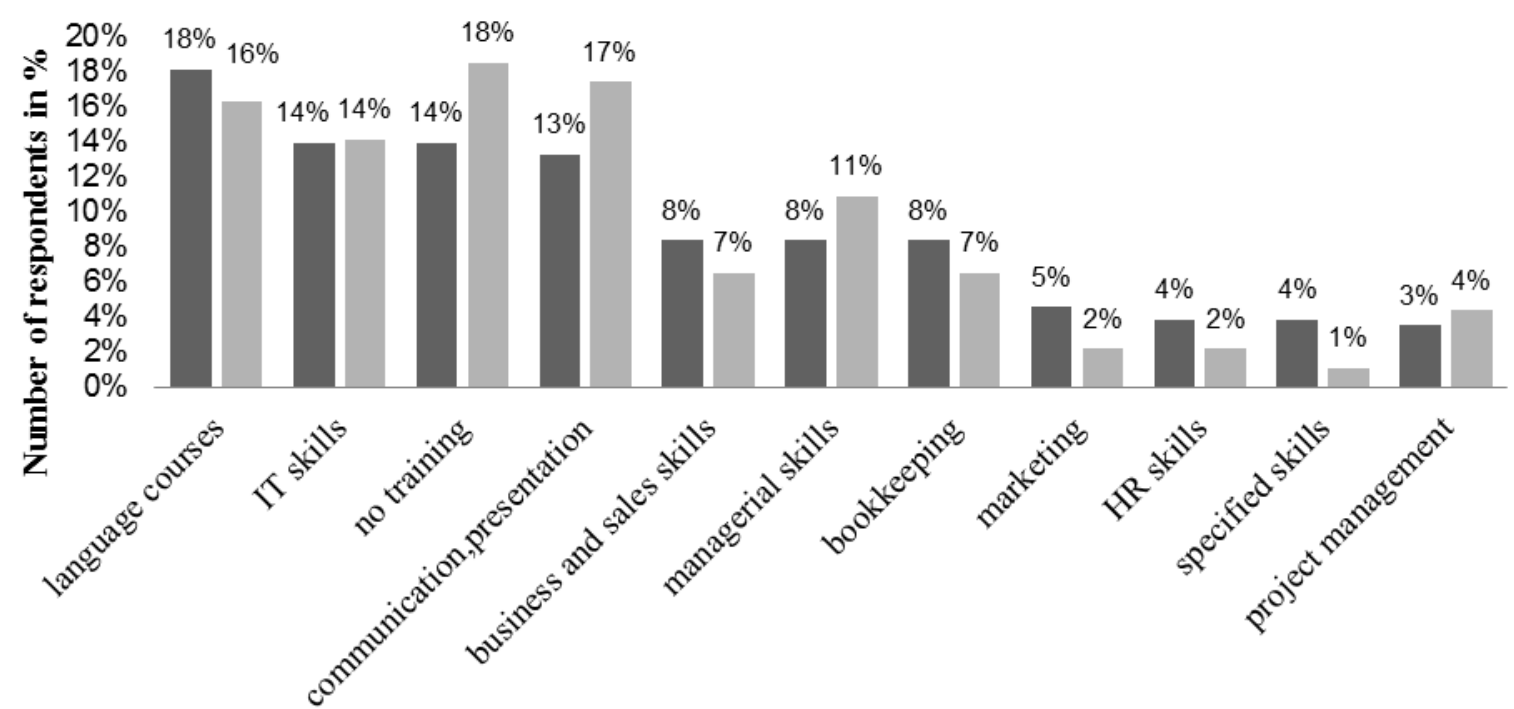

Specialisation of company training

- $2013 \square 2014$

Source: author's own adaptation, [17]

Fig. 2: $\quad$ Specialisation of training provided to employees in 2013 and 2014

Even if many companies indicate investing in training as being a crucial factor of making investments in human capital, it is surprising that when comparing 2013 with 2014, there was an increase in the percentage of those who received no training in their occupation (in total, $18 \%$ ). Trends in the frequency of training (Figure 3) show that the most common reason to train these employees is based on the needs of the employees. However there was a decrease by about $10 \%$ in 2014. The percentage of part-time students trained once per year increased by $12 \%$ in 2014. It can be seen in Figure 3 that not many companies care about systematic frame of training which was mentioned in the first part of the paper as an important part of development of competencies.

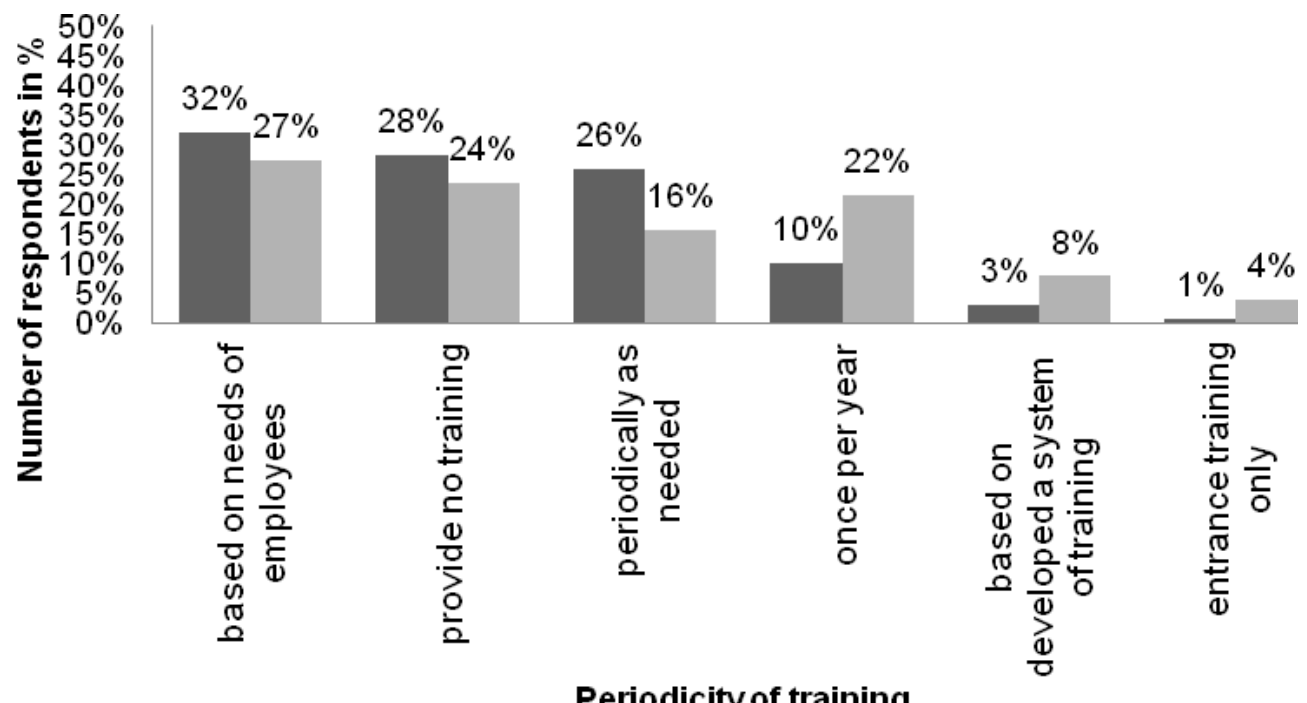

-2013 2014

Source: author's own adaption, [17]

Fig. 3: Periodicity of employee training in 2013 and 2014 
Companies can use different methods to train employees depending on whether on-the-job or off-the-job training is used. These methods were introduced in Table 1. A comparison of the methods indicated by part-time students working in companies is shown in Figure 4.

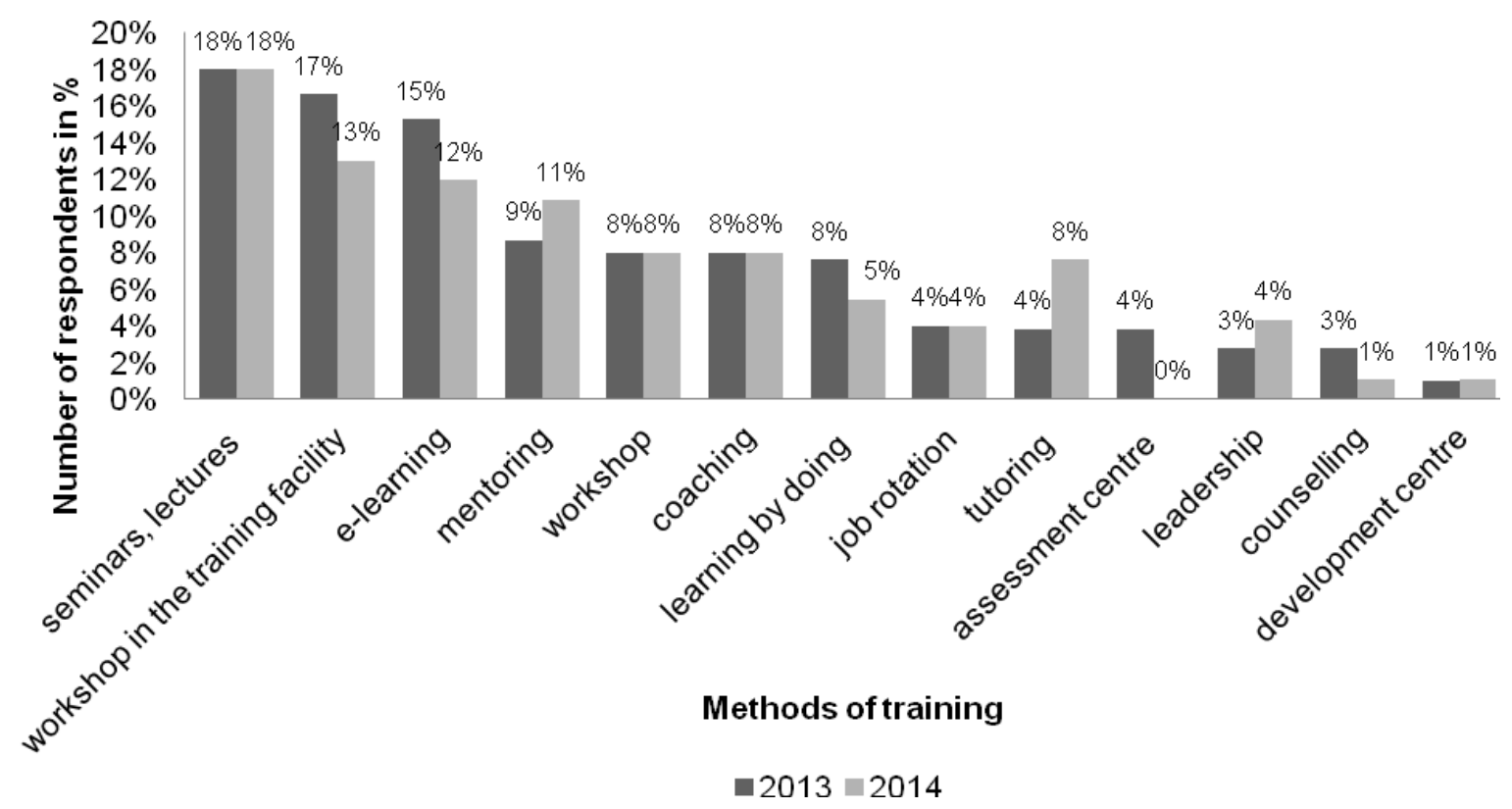

Source: author's own adaptation, [17]

Fig. 4: The methods of training provided to employees in Czech companies

\section{$5 \quad$ Research limitations}

Findings in the first part of the paper show that training trends are generally moving from more conservative methods such as lectures and seminars to more interactive methods such as workshops and development centres. However, the respondents of the primary data surveys stated seminars and lectures as being the most common in both years. E-learning, which allows trained employees to use information as needed, is also relatively popular. In view of the fact that chosen method of this survey has limitations it is not possible to generalize findings. However the authors hope to bring broadening of updated information about position of training and indicate trends in Czech companies.

\section{Conclusion}

From the information and data presented above, it is evident that employee training influences the quality of employees as well as the conditions within a firm and its business results. Investing in training is a way to increase the value of a company's human and intellectual capital. On the other hand, such investment is necessary to organise systematically and effectively to ensure the highest returns from such an investment.

As Cedefop emphasizes, in a global and competitive economic environment there is an everincreasing recognition in firms of the continuously changing skill demands within occupations [8]. Lifelong learning has therefore become an issue of a paramount concern for modern organisations and policymakers [18].

As the results in this paper indicate, companies can use different methods to train employees and they can also have different reasons to decide about training. As presented both in the primary and secondary data of this paper, in these surveys traditional methods such as seminars and lectures were indicated as the most popular. Forms of on-the-job training were used more often for administrative staff and managers, which is confirmed by the data about 
mentoring and training in firms. Trends in training are focused on modern methods such as elearning, blended learning and gamification. Although the data introduced in this paper are limited in their scope and representativeness, they provide an incentive for both companies and employees to follow up training as an important part of HR activities. Data from companies confirm important reserves in such investments. The results presented in this paper confirm the importance of training both from the employees' and firms' points of view.

\section{Literature}

[1] ACCENTURE: Accenture 2013 skills and employment trends survey: Perspectives on training. [online]. 2014-08-28 [accessed 2015-03-03]. Available from WWW: http://www.accenture.com/us-en/Pages/insight-accenture-2013-skills-employmenttrends-survey-perspectives-on-training.aspx

[2] AGUINIS, H.; KRAIGER K.: Benefits of training and development for individuals and teams, organizations, and society. Annual Review of Psychology. 2009, Vol. 60, pp. 451-474. ISSN 0066-4308. DOI: 10.1146/annurev.psych.60.110707.163505.

[3] ARAGON, I. S.; VALLE, R. S.: Does Training managers pay off? The International Journal of Human Resource Management. 2013, Vol. 24, Issue 8, pp. 1671-1684. ISSN 0958-5192. DOI: 10.1080/09585192.2012.725064.

[4] ARAGÓN-SÁNCHEZ, A.; BARBA-ARAGÓN, I.; SANZ-VALLE, R.: Effects of training on business results. The International Journal of Human Resource Management. 2003, Vol. 14, Issue 6, pp. 956-980. ISSN 0958-5192. DOI: $10.1080 / 0958519032000106164$.

[5] ARMSTRONG, M.: Řízení lidských zdrojů. $1^{\text {st }}$ ed. Praha: Grada, 2002. ISBN 8024704692.

[6] BECKER, G. S.: Human capital, a theoretical and empirical analysis with special reference to education. $3^{\text {rd }}$ ed. Chicago, Illinois: University of Chicago Press, 1993. ISBN 0226041204.

[7] BELCOURT M.; WRIGHT, P. C.: Vzdělávání pracovníki̊ a řizení pracovního výkonu. 1st ed. Praha: Grada Publishing, 1998. ISBN 80-7169-459-2.

[8] CEDEFOP: Skills for Europe's future: anticipating occupational skill needs. [online]. Luxembourg, Publications Office of the European Union, 2009. [accessed 2015-03-03]. Available from WWW: http://www.cedefop.europa.eu/EN/Files/5194_en.pdf

[9] CEDEFOP: The benefits of vocational education and training. [online]. Luxembourg, Publications Office of the European Union, 2011. [accessed 2015-03-03]. Available from WWW: http://www.cedefop.europa.eu/EN/Files/5510_en.pdf

[10] CEDEFOP: Skill mismatch: The role of the enterprise. [online]. Luxembourg, Publications Office of the European Union, 2012. [accessed 2015-03-03]. Available from WWW: http://www.cedefop.europa.eu/EN/Files/5521_en.pdf

[11] ING: Zaměstnanecké benefity na konci ekonomické krize. [online]. 2014. [accessed 2015-03-03]. Available from WWW: http://www.spcr.cz/images/ING/ING.pdf

[12] KOUBEK, J.: Ǩizení lidských zdrojů: základy moderní personalistiky. 5th ed. Praha, Management Press, 2015. ISBN 978-80-7261-288-8.

[13] LAZEAR, E. P.: Personnel Economics for Managers. $1^{\text {st }}$ ed. New York, John Wiley \& Sons, 1998. ISBN 0471594660. 
[14] O'DONNELL, D.; O'REGAN, P.: The structural dimensions of intellectual capital: Emerging challenges for management and accounting. Southern African Business Review. 2000, Vol. 4, Issue 2, pp. 14-20. [online]. 2001. [accessed 2015-03-03]. Available from

WWW: http://reference.sabinet.co.za/webx/access/journal_archive/1561896X/294.pdf

[15] SAKS, A. M.; BURKE-SMALLEY, L. A.: Is transfer of training related to firm performance? International Journal of Training and Development. 2014, Vol. 18, Issue 2, pp. 104-115. ISSN 1468-2419. DOI: 10.1111/ijtd.12029.

[16] KREIGER, K.: Perspectives on Training and Development. Handbook of Psychology. pp. 171-192. John Wiley \& Sons, 2003. DOI: 10.1002/0471264385.wei1208.

[17] MARŠÍKOVÁ, K.; SPURNÁ, G.: Efficient Company Training in Case of Companies in the Czech Republic. ACC Journal. 2014, Vol. 20, Issue B(2), pp. 17-30. ISSN 18039782.

[18] TURECKIOVÁ, M.; VETEŠKA, J.: Význam kvalifikací a kompetencí v profesním vzdělávání dospělých. In: Smišený design v pedagogickém výzkumu: Sborník přispěvků z 19. výroční konference České asociace pedagogického výzkumu. 2011, pp. 62-67. Brno, Masarykova univerzita. DOI: 10.5817/PdF.P210-CAPV-2012-79.

[19] EUROSTAT: Vocational education and training statistics. [online]. 2013. [accessed 2015-12-03]. Available from WWW: http://ec.europa.eu/eurostat/statisticsexplained/index.php/Vocational_education_and_training_statistics

Ing. Kateřina Maršíková, Ph.D.; Ing. Eva Šlaichová, Ph.D. 


\section{PERSPEKTIVY VZDĚLÁVÁNÍ A ROZVOJE ZAMĚSTNANCŮ: METODY A PŘÍSTUPY}

Cílem př́spěvku je podat aktuální přehled o trendech, metodách a prrístupech $\mathrm{v}$ oblasti vzdělávání zaměstnanců. Článek prezentuje primární a sekundární data vybraných průzkumů. Data prezentovaná v př́spěvku dokládají potřebu a význam vzdělávání zaměstnanců jako důležitou formou investice do lidského kapitálu, která generuje přidanou hodnotu a zvyšuje produktivitu v podniku. Současně má vliv na lidský kapitál ve společnosti. Potřeby vzdělávání zaměstnanců jsou z pohledu podniku i jednotlivce různé. Společnosti používají mnoho metod, které jsou popsány $\mathrm{v}$ první části př́íspěvku. Druhá, empirická část, porovnává význam vzdělávání v mezinárodním kontextu na sekundárních datech. Závěrečná část dokresluje oblast firemního vzdělávání na primárních datech získaných od respondentů v letech 20132015. Výsledky ukazují, že v některých českých firmách není vzdělávání zaměstnanců systematicky a zvyšování kvalifikace zaměstnanců firmy téměř nepodporují. Kromě toho i sekundární data z průzkumů poukazují na to, že stále existuje značný počet firem, které svým zaměstnanců další vzdělávání neposkytují.

\section{PerspeKTiVen Schulung Und EnTwicklung DER MitaRbeiter: Methoden UND ANSÄTZE}

Ziel dieser Arbeit ist es, einen aktuellen Blick auf Trends, Methoden und Ansätze der Mitarbeiterweiterbildung im Unternehmen zu bringen, sowie Primär- und Sekundärdaten aus Erhebungen darzustellen. Basierend auf Erkenntnissen von Wissenschaftlern und HRSpezialisten ist die Schulung der Mitarbeiter eine wichtige Form der Investition in Unternehmen, um Mehrwert zu erzeugen und die Produktivität der Unternehmen zu steigern. Gleichermaßen hat es einen Einfluss auf das Humankapital der Mitarbeiter. Unternehmen können unterschiedliche Motive haben, Mitarbeiter zu schulen und dazu verschiedene Methoden nutzen, welche im ersten Teil dieser Arbeit beschrieben werden. Der zweite Teil des Artikels vergleicht Sichtweisen auf das Training in europäischen Unternehmen und in den USA. Im letzten Teil werden Methoden und Gründe der Weiterbildung anhand einer Stichprobe von tschechischen Befragten vorgestellt. Die Ergebnisse zeigen, dass die Ausbildungsschemata nicht systematisch sind oder gar in einigen tschechischen Firmen überhaupt nicht existieren. Sekundärdaten aus Erhebungen weisen auch darauf hin, dass eine erhebliche Anzahl an Unternehmen überhaupt keine betriebliche Weiterbildung anbietet.

\section{PERSPEKTYWY ROZWOJU I SZKOLENIA PRACOWNIKÓW: METODY I PODEJŚCIA}

Celem niniejszego opracowania jest przybliżenie aktualnych poglądów na temat trendów, metod i sposobów szkoleń w firmach poprzez prezentację danych pierwotnych oraz wtórnych pozyskanych z ankiet. Opierając się na odkryciach naukowców oraz specjalistów do spraw zasobów ludzkich, szkolenia pracowników są istotną formą inwestycji w firmach, generującą wartość dodaną i zwiększającą produktywność firmy. Jednocześnie ma to wpływ na kapitał ludzki pracowników. Szkoląc pracowników przedsębiorsta kierują sie różnymi motywami i stosują różne metody, które są opisane w pierwszej częsci pracy. Druga część pracy porównuje uwarunkowania szkoleń w firmach europejskich i amerykańskich. W ostatniej części pracy przedstawiono metody i powody szkoleń przeprowadzonych na próbie czeskich respondentów. Wyniki pokazują, iż niektóre czeskie firmy nie posiadają uporządkowanego systemu szkoleń lub system szkoleń w ogóle nie istnieje. Również dane wtórne przeprowadzonych badań wskazują na znaczną ilość przedsiębiorstw nie oferujących firmowych szkoleń pracowników. 